\title{
A Non-parametric Estimation for Efficacy of Government Expenditure on Secondary Education
}

\author{
Moumita Khowas, Supravat Bagli
}

\begin{abstract}
The paper is aimed to analyse the efficacy of government expenditure on secondary education in Purulia district of West- Bengal, India. Efficacy relates the input or the output to the final objectives of the analysis to be achieved, i.e. the outcome. Education facility is mainly a mixed good which is partly excludable and partly rivalry. India has been suffering from poverty and illiteracy problem for decades. Illiteracy and low level of education is a factor for widespread poverty in India. Among the education system, secondary education plays a crucial role to enhance the human development level which ultimately contributes in development process. So, government should give emphasis on secondary education and it should be concerned about the efficacy of the government expenditure on secondary education. As in the present scenario, the structural adjustment policy (SAP) leads to some sort of cut back on expenditure on education. This study first calculates the technical efficiency as well as the scale efficiency of government expenditure on secondary education of school using Data Envelopment Analysis (DEA), then categorize the schools into low, moderate and high according to the value of technical efficiency and scale efficiency based on three models (i) considering all inputs (Teacher Student Ratio, Expenditure per Student, \% of Students belong to SC, \% of Students belong to ST, \% of Students belong to OBC, \% of Teacher with Professional Qualification, Student- Classroom Ratio, \% of Girl's Student Enrolment) (ii) considering prime two inputs (Student-Teacher Ratio and Expenditure per Student) and (iii) considering only one input (Expenditure per Student) and try to find out the reason of differences in efficiency. The common set of schools from High, Moderate and Low efficiency schools considering above said three models are further analysed with the primary data collected from the student sets to analyse whether the school efficiency affect the student's individual performance or not with the help of regression analysis.
\end{abstract}

Keywords: Efficacy, Technical Efficiency, Scale Efficiency, VRS, CRS, DEA.

\section{INTRODUCTION}

In India the provision of Education is included in the Concurrent List of the Indian Constitution after its $42^{\text {nd }}$ Amendment Act, 1976. The central and state governments both have the power to take education policies and allocate the fund for improvement of education facility. Education has

Revised Manuscript Received on January 29, 2020.

* Correspondence Author

Moumita Khowas *, Research Scholar, Department of Economics, SKBU Purulia, India. Email: moumita_khowas@yahoo.com

Supravat Bagli, Department of Economics, Presidency University, Kolkata, India. Email: supravat.bagli@gmail.com

(C) The Authors. Published by Blue Eyes Intelligence Engineering and Sciences Publication (BEIESP). This is an open access article under the CC BY-NC-ND license (http://creativecommons.org/licenses/by-nc-nd/4.0/) a great positive consumption externality to the whole society. It is basically a mixed good. Market for the mixed goods cannot ensure the socially optimum level of output. In this circumstance's government intervention is necessary for achieving the socially optimum outcome for education facility at any level. Sometimes government provision of education facility may be considered as a merit good understanding its social benefit greater than the personal benefit of the consumer. So, the Government should allocate fund in the education sector for improving social welfare. However, in the present scenario, the SAP in India leads to some sort of control on government expenditure on education. Against this backdrop, it should be the prime concern of the government to give emphasis on the efficiency of the fund utilization.

All business and government sectors involved in the production process are often interested in evaluating how efficiently various processes operate with respect to the use of resources. Efficiency in government spending is a benefit that generates value for taxpayers, ensures that the costs of taxation and government intervention for economic growth and market performance are minimized. Effectiveness(efficacy) relates the input or the output to the final objectives to be achieved, i.e. the outcome. The outcome is often linked to welfare or growth objectives and therefore may be influenced by multiple factors (including outputs but also exogenous 'environment' factors). The effectiveness is more difficult to assess than efficiency.

Education is a prime mover of a society. The primary justification for investment in secondary education lies in its contribution to economic growth, social equity and poverty reduction. Analysis shows steadily rising rates of return to secondary and senior secondary education, reflecting that demand for knowledge and skills gained at the secondary level (fueled by economic growth) has increased faster than supply. Public investment can accelerate the response to this skills demand and overcome certain market failures which would result in underinvestment in secondary education by the private sector alone.

The SAP continued fiscal crisis, slow growth of economies and rising unemployment led to some sort of control on expenditure on education. Yet India's per student public spending on secondary education as a percentage of GDP (Gross Domestic Product) per capita is somewhat high compared to a benchmark for fast-growing economies [1].

Published By:

Blue Eyes Intelligence Engineering DOI:10.35940/ijmh.F0582.024620

Journal Website: www.ijmh.org

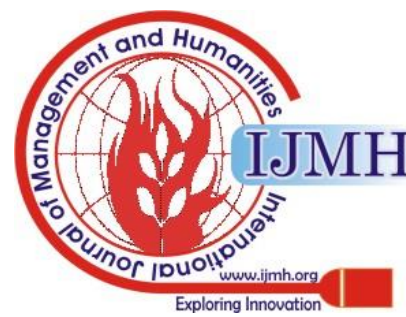


International experience suggests such a high ratio constitutes a major challenge in achieving financially sustainable massification of secondary education by government. Sustainable expansion of secondary education will require efforts to control unit costs where possible. In such a situation a great emphasis should be given on the efficacy of govt expenditure in secondary education.

The paper is organized as follows: Section 2 deals with the literature review. Section 3 deals with the sampling design and methodology and in Section 4 results are cited with description. Finally, section 5 draws the conclusion.

\section{LITERATURE REVIEW}

A substantial literature related works is available in Indian as well as international scenario. In Indian scenario, Tilak [2] suggested to focus on the method of resource assignment to the education without perceiving the contribution that education has made towards the economic growth of the country and opined that the coefficient of correlation between the SDP spent on education and SDP per capita is estimated to be small, negative, and statistically not significant. Chatterjee [3] tried to find out the rate of return to education using 1966-1996 data and he observed that the return rate was high in case of secondary education and under developmental areas. Khilar [4] assessed the quality and the economics of school education and compared the assessed quality of education in private schools with that of the government schools in Sikkim. As per his study, private schools are profit making organizations, but they maintain the quality of education as compared to government schools. Jana [5] investigated the efficiencies of 11 universities in West Bengal by applying DEA. He observed that there is extensive difference in efficiency scores of the universities and also found some discrepancy between ranks of NAAC scores and efficiency scores. Jana [6] tried to assess the quality of higher education in the state of West Bengal in India by applying six Sigma DMAIC approach to facilitate policy formulation for improving teaching and learning process in higher education.

In international level, Kirjavainen and Loikkanent [7] studied the efficiency differences among Finnish senior secondary schools by Data Envelopment Analysis (DEA). The report displayed that the government schools accomplish better than private schools. The education level of the parents affected the efficiency positively in the Tobit model. Gupta and Verhoeven [8] assessed the efficiency of government expenditure on education and health in 37 countries in Africa in 1984-1995. They concluded that the African countries are less effective than Asian countries and the countries of the Western Hemisphere as per the obtained results. Millington.et.al [9] calculated the technical efficiencies, based upon multiple outputs - school exam performance and attendance rates - of all secondary schools in England over the period 1993-1998 The analysis showed that the efficiency of the schools was directly related to the competition between the schools. Baldacci et al. [10][11] estimated a non-linear model to capture the spending-outcome relationship using panel data from 118 developing countries in 1971-2000.As per the authors, the public expenditure has a direct effect on the outcomes of education. It is found that poor governance does not lead to expected educational outcomes even if the public spending on education is high. Johnes [12] applied DEA to a data set of more than 100 High Educational Institutions (HEIs) in England using data for the year 2000/01. They came with a conclusion that the efficiency values calculated using DEAs at the aggregate level, including individual and institutional sub-components were misleading. Polat [13] found scale diseconomies and combined them with the basic aspects of the education system using DEA (Data Envelopment Analysis) and econometric mechanisms. A significant relationship was found between centralization indicators and scale diseconomies. Ayadib.et.al [14] used a non-parametric mechanism, i.e., DEA (Data Envelopment Analysis) to various inputs as well as outputs to find the reasons which enhances the efficacy of elementary and intermediate education in 24 Tunisian governorates for the year 1999, 2003, 2006 and 2008 respectively. According to their results, there was a lack of an important association between performance of the students and the resources of the school and the incompetence's in education was having a direct relation to poverty in the case of the governorates. Hužvár and Rigová [15] has analysed the comparative efficiencies of expenditure on the education in OECD countries during 2000-11. They have also designed two DEA models that show the uncertain nature of the student to teacher ratio and its explanation by changing the student and teacher's part as inputs and outputs of the academic system respectively. It is concluded that the countries whose efficiency is high in both the models have a balanced student to teacher ratio irrespective of their socioeconomic conditions. Zolfaghari.et.al [16] have reviewed the information to enhance the inequity potential of the analytical technique i.e. DEA (Data Envelopment Analysis). The results of this paper are useful to those who applies the DEA calculation over any data set to find the best fit ranking method. Aparicio et. al [17] have calculated the effectiveness of the schools in a mixed country framework using data from OECD countries who have taken part in PISA 2012 using DEA. The research report has concluded that most of the schools appear to be less effective in reading as compared to mathematics in the OECD countries.

After a rigorous literature study, the following research gap is observed:

(i) Limited micro level work available in literature.

(ii) Research available on secondary data considering very limited inputs

\section{DESIGN METHODOLOGY}

Our initial objective is to estimate the local pure efficiency (T.E, VRS) of government expenditure of secondary public schools of Purulia district of year 1916-17 using Data Envelopment Analysis (DEA) methodology to assess whether the schools can use the inputs efficiently or not. In addition to this, we intend to study the optimal utilization of the scale of production. To fulfil this purpose, we calculate the scale efficiency (S.E). For that we have collected secondary data from the DISE format of 121 schools out of total 379 secondary schools of Purulia district where the concerned data are available.

Published By:

Blue Eyes Intelligence Engineering DOI:10.35940/ijmh.F0582.024620

Journal Website: www.ijmh.org

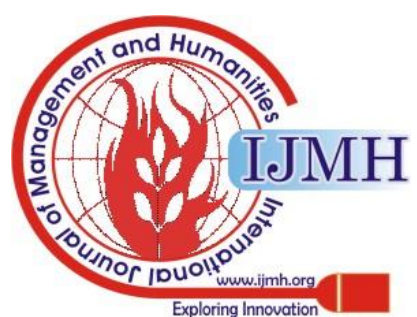

\& Sciences Publication 


\section{A. Methodology for Estimating Technical Efficiency} (T.E.)

We use the following DEA model. It is an input-oriented model where the inputs are minimized, and the outputs are kept at their current levels as shown in Equation (i).

$$
\theta^{*}=\min \theta
$$

Subject to

$$
\begin{aligned}
& \sum_{j=1}^{n} \lambda j x_{\mathrm{ij}} \leq \theta x_{\mathrm{i}} \text { where } i=1,2, \ldots \ldots \ldots, m \\
& \sum_{j=1}^{n} \lambda j y_{\mathrm{rj}} \geq y_{\text {ro }} \text { where } r=1,2, \ldots \ldots \ldots, s \\
& \sum_{j=1}^{n} \lambda j=1 \\
& \lambda j \geq 0 \quad \text { where } j=1,2, \ldots \ldots \ldots \ldots
\end{aligned}
$$

where DMUo indicates one of the $n$ DMUs underestimation, and $x_{i o}$ and $y_{\text {ro }}$ are the ith input and $r$ th output for DMUo, respectively, the optimal value to equation (i), $\theta^{*} \leq 1$.

If $\theta^{*}=1$, then the current input levels cannot be reduced (proportionally), indicating that $D M U o$ is on the frontier. Otherwise, if $\theta^{*}<1$, then $D M U o$ is dominated by the frontier. $\theta^{*}$ represents the (input-oriented) local pure efficiency i.e. T.E under VRS score of DMUo.

We have considered, $\mathrm{i}=$ number of inputs, $\mathrm{r}=$ number of output and $\mathrm{j}=$ the number DMUs.

Here, $\theta$ represents efficiency score and $\lambda$ represents dual variable that identify the benchmarks for inefficient units. We construct three models considering different number of inputs to calculate input-oriented Variable Return to Scale (VRS) envelopment efficiency and Scale Efficiency (SE).

\section{- Model 1: Considering all inputs}

Inputs considered are: Teacher Student Ratio, Expenditure per student, \% of Students belong to SC, \% of Students belong to ST, \% of Students belong to OBC, \% of teacher with professional qualification, Student- Classroom Ratio, \% of girl's student enrolment and the Output is: Promotion rate. Here, $\mathrm{m}=8$ and $\mathrm{s}=1$ and the number of DMU (schools) $=121$.

\section{- Model 2: Considering two inputs}

Inputs considered are: Inputs considered are: Expenditure per student and Teacher Student Ratio and output is: Promotion Rate. Here, $\mathrm{m}=2$ and $\mathrm{s}=1$ and the number of DMU (schools) $=121$.

\section{- Model 3: Considering one input}

Considered input is: Expenditure per student and output is: Promotion Rate. Here, $\mathrm{m}=1$ and $\mathrm{s}=1$ and the number of DMU (schools) $=121$.

We use the input oriented VRS envelopment model (DEA) in spreadsheet since our objective is to minimize the government expenditure spending on Secondary Education to obtain a certain level of output. After the DEA model is set up in the spreadsheet, we use Solver software tool to find the optimal solutions. For solving the model first, we properly set the objective cell and change the variable cells in Solver tool and then add the constraints and finally select the solving method. Since DEA models are linear models, we should select "Simplex LP" in solving method option. We provide the Visual Basic for Applications (VBA) code to automate the DEA computation. Using this VBA code, we can get easily the efficiency values under VRS for all 121 schools in one time, instead of computing 121 times for121 schools i.e. one time for each school. After arranging the values of efficiency in ascending order, we basically categorize the obtained efficiency values of 121 schools into three categories namely low efficiency, medium efficiency, high efficiency as based on (mean $\pm 1 / 2 *$ S.d.).

\section{B. Methodology for Estimating Scale Efficiency (S.E)}

We need to find out constant return to scale (CRS) efficiency score, since the ratio of CRS efficiency scores to VRS efficiency scores is called scale efficiency (SE) score i.e. SE $=(C R S$ score $/ V R S$ score $)$.

To find out CRS efficiency score, in solver parameter we exclude the constraint $\Sigma \lambda=1$ of equation (1) just mentioned above. We get CRS efficiency for 121 schools in a column of a spreadsheet and in the next column of that spreadsheet we divide CRS efficiency by VRS efficiency to get S.E for 121 schools. We carry out the same procedure for three models which we have used for finding out VRS efficiency, namely, Model 1: Considering all inputs, Model 2: Considering two inputs, Model 3: Considering one input

C. Methodology for finding out the relationship between the Technical Efficiency and the Inputs and Output: SPSS technique is used for finding out the correlation between the technical efficiency and the inputs and output. This technique is also used to test whether the relationships among the technical efficiency and the different inputs and outputs are statistically significant or not. Generally, it is expected that inputs like student-teacher ratio, student classroom ratio,\% of S.C students ,\% of S.T students,\% of O.B.C students,\% of girls enrolment are inversely correlated with efficiency while inputs like the expenditure per student, percentage of teacher with professional qualification and the output promotion rate are positively correlated with efficiency.

D. Methodology for Estimating the Impact of T.E on Personal Achievement of Students: -We apply least squares method to assess the testing of hypothesis to test different hypotheses regarding the impact of T.E and related environmental factors on personal achievement of students. In our research work, we find out 20 common schools which are common in three models considering each category one by one and collect primary data using questionnaire's format from those 20 chosen schools for finding out the impact of the efficiency of the government expenditure on personal achievement of students. We first categories the students according to their caste and gender and then try to choose students randomly and equally from each category as per availability. From each school we collect data from 10 students. In this way we collect 200 filled up questionnaires' form. From the information of questionnaires', we arrange the data as per our requirement.

\section{RESULTS AND DISCUSSIONS}

In this section, first we would like to present a statistical description of the inputs and output based on the collected secondary data as shown in Table I. After taking a view on inputs and output at a glance, we find out the technical efficiency and scale efficiency of the 121 schools under the model of considering all inputs.

Published By:

Blue Eyes Intelligence Engineering DOI:10.35940/ijmh.F0582.024620

Journal Website: www.ijmh.org

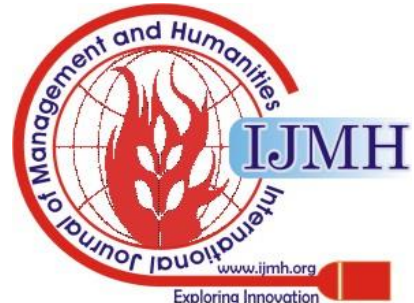

\& Sciences Publication

(C) Copyright: All rights reserved. 


\section{A. Technical Efficiency considering all inputs}

In the first step, we calculate efficiencies considering all inputs and the

calculated efficiencies are arranged in ascending order and categorize into three categories: - (1) low (2) moderate and (3) high.

There are total 21 schools belonging to the low technical efficiency under VRS as shown in Figure1. School with lowest efficiency value is "Ghonga High School" and School with highest efficiency value is "Chakalta Bhagabandh High School" belonging to the low technical efficiency group. The range of efficiency value lies between 0.622 to 0.797 . There are total 44 schools belonging to the moderate technical efficiency under VRS as shown in Figure 2. School with lowest efficiency value is "Manbazar Girls' High School" and School with highest efficiency value is "Sasa Netaji Adarsha High School" belonging in the moderate technical efficiency group. The range lies between 0.802 to 0.993 . There are total 56 schools belonging to the high technical efficiency considering all inputs under VRS as shown in Figure 3. All schools belonging to this category have efficiency value 1 . Out of 121 schools, only 56 schools utilize the minimum inputs to achieve the certain level of output.

Below we present the graphical representation of all input's vs efficiency for low efficiency schools, moderate efficiency schools, and high efficiency schools.

In the graphs in Figure1, Figure2 and Figure 3 all the inputs and efficiency values are plotted in an integrated way. All inputs are plotted along the primary axis and efficiency is plotted along the secondary axis. The number of schools are plotted along the horizontal axis.

The correlation between the efficiency and different inputs are shown in Table II. It is observed that the Pearson correlation coefficient between efficiency and expenditure per student is -.113 which is not statistically significant. The correlation between the efficiency and four variables like pupil -teacher ratio, student-classroom ratio, \% girls' enrolment, \% teacher with professional qualification are statistically significant. We get negative value of the Pearson correlation coefficient in these cases which are expected, except in case of \% teacher with professional qualification

\section{B. Scale Efficiency considering all inputs}

There are 24 schools belonging to the low scale efficiency group considering all inputs. School with lowest efficiency value is "Lagda Girls High School" and School with highest efficiency value is "Ladhurka High School. (H.S.)" belonging to the low scale efficiency group. The range of efficiency value lies between 0.375978 to 0.849704 . There are 35 schools belonging to the moderate scale efficiency group considering all inputs. School with lowest efficiency value is "Barrah Anchal High School" and School with highest efficiency value is "Pukurgoria Bibhutinath Vidyapith" belonging to the moderate scale efficiency group. The range of efficiency value lies between 0.869292 to 0.983735 . There are 62 schools belonging to the high scale efficiency group considering all inputs. School with lowest efficiency value is "Sasa Netaji Adarsha High School" and school with highest efficiency value is "Biltora High School" belonging to the high scale efficiency group. The range of efficiency value lies between 0.985961 to1. There are 41 schools having 1 . This implies that only 41 schools optimally utilise their scale.

\section{Technical and Scale Efficiency for Common Schools}

The common schools are chosen from the above said three models considering three categories namely Low, Moderate and High Efficiency group of schools (discussed in Design Methodology section). The Technical and Scale efficiencies of those common schools are shown in Figure 4, Figure 5 and Figure 6 respectively.

It is observed that the Scale Efficiency for both Low and Moderate Efficiency Schools are higher than the Technical Efficiency for most of the cases whereas in case of high efficiency Schools both produces same value in all of the cases. The interesting phenomenon observed in case of highly efficient schools is that they all fully utilize the scale of production along with the minimum utilisation of inputs to achieve a certain amount of output.

\section{Findings with Primary Data}

We make the studies with the help of two types of data. Above we have made a rigorous study on the research topic with the help of secondary data. First, in this section,

we would like to present a statistical description of the socio-economic variables( sex of the student, mother education, education of the head of the family ,family belong to income group, caste, family type, worker population ratio, farm occupation, tuition fee spend on the study of the student, regularity above 80 percent.) representing the characteristics of 200 sampled students based on the collected primary data as shown in Table III.

Next, we present the result of the analysis of the assessment of the impact of the technical efficiency under VRS and the socio-economic variables or the environmental factors on students' personal achievements in the Table IV.

Table-I: Statistical description of the inputs and output

\begin{tabular}{|c|c|c|c|c|c|c|}
\hline & Mean & Median & Mode & Standard Deviation(S.D) & Minimum & Maximum \\
\hline pupil-teacher ratio & 49.30578512 & 48 & 48 & 14.50566 & 18 & 101 \\
\hline student-classroom ratio & 69.84166667 & 71.5 & 77 & 20.83589 & 15 & 130 \\
\hline$\%$ of girls' enrolment & 52.3992562 & 50.41 & 100 & 23.18931 & 0 & 100 \\
\hline$\%$ of SC student & 23.86438017 & 21 & 6.95 & 16.78944 & 0 & 78.3 \\
\hline$\%$ of ST student & 16.51669421 & 11.7 & 0 & 16.2691 & 0 & 77.78 \\
\hline$\%$ of OBC student & 37.56603306 & 37.1 & 0 & 22.25643 & 0 & 86.68 \\
\hline \% of teacher with professional qualification. & 68.79652893 & 68 & 66.67 & 16.05232 & 8.95 & 100 \\
\hline expenditure per student & 64.13651105 & 21.25 & \#N/A & 160.7171 & 0.686813 & 1239.598 \\
\hline promotion rate & 73.23991736 & 76.09 & 84.31 & 15.56812 & 30.2 & 100 \\
\hline
\end{tabular}

(Source: Own computation by author based on secondary data) 


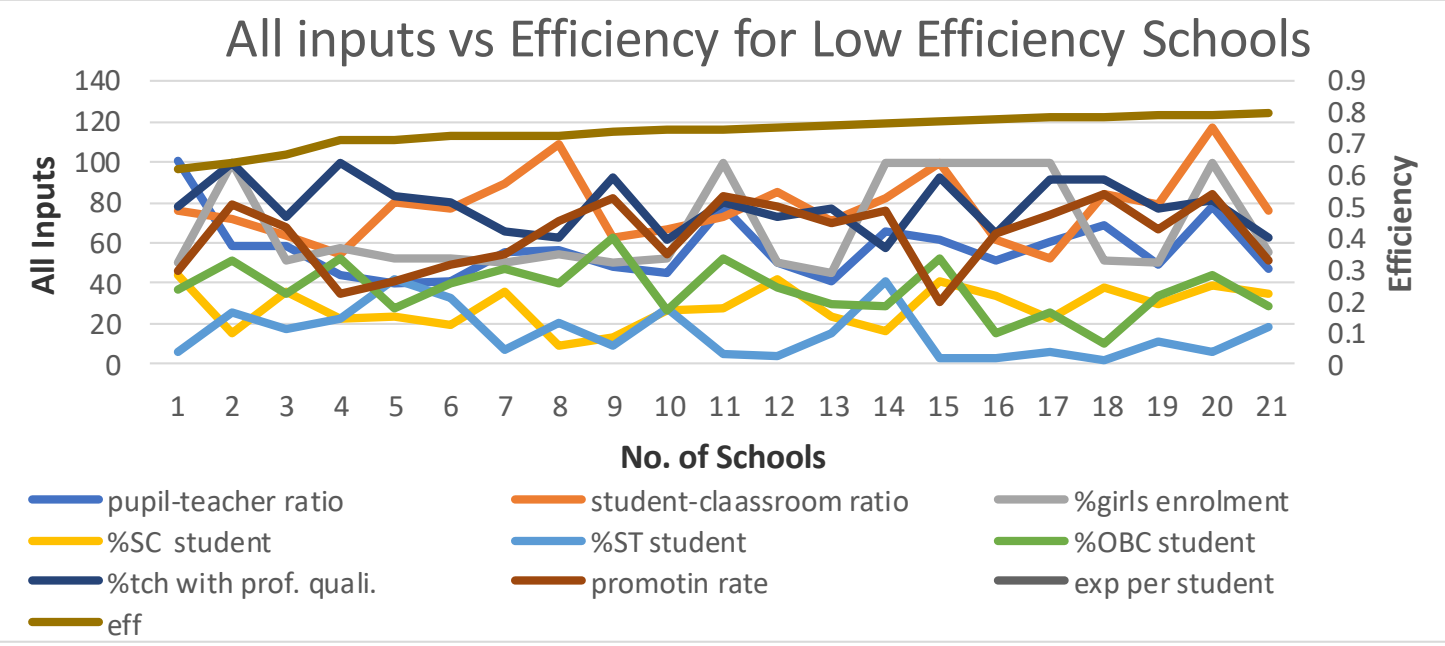

Fig. 1. All inputs vs efficiency graph for Low Efficiency Schools

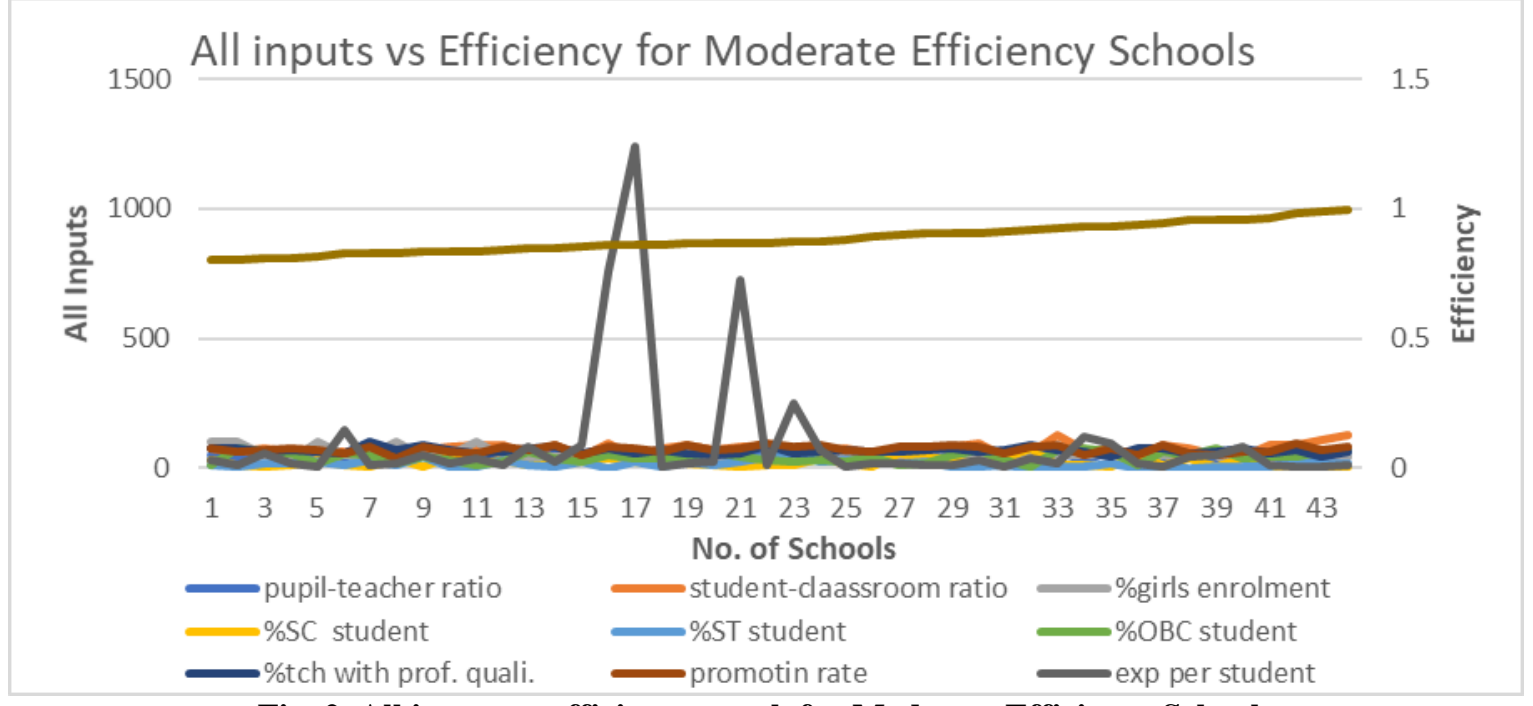

Fig. 2. All inputs vs efficiency graph for Moderate Efficiency Schools

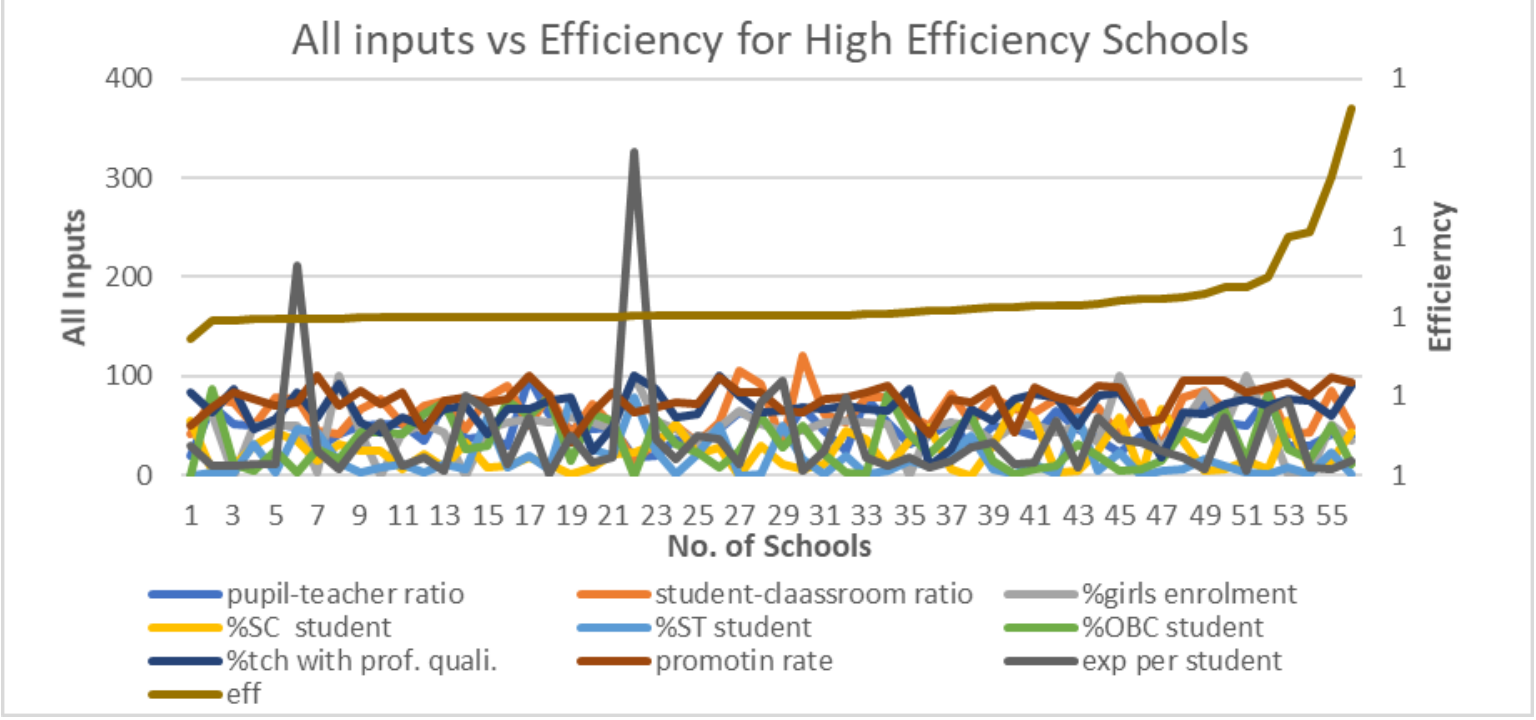

Fig. 3: All inputs vs efficiency graph for High Efficiency Schools

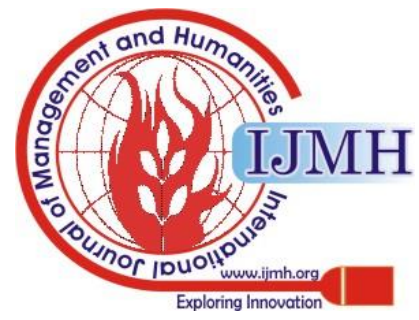


A Non-parametric Estimation for Efficacy of Government Expenditure on Secondary Education

Table-II: The correlation between efficiency and different inputs

\begin{tabular}{|c|c|c|c|c|c|c|c|c|c|c|}
\hline & & $\begin{array}{c}\text { pupil-teacher } \\
\text { ratio }\end{array}$ & \begin{tabular}{|c|}
$\begin{array}{c}\text { student-claassroom } \\
\text { ratio }\end{array}$ \\
\end{tabular} & \begin{tabular}{|c|} 
\%girls \\
enrolment
\end{tabular} & $\begin{array}{c}\% \mathrm{SC} \\
\text { student }\end{array}$ & $\begin{array}{c}\text { \%ST } \\
\text { student }\end{array}$ & $\begin{array}{c}\text { \%OBC } \\
\text { student }\end{array}$ & $\begin{array}{c}\text { \% teacher with } \\
\text { professional } \\
\text { qualification }\end{array}$ & $\begin{array}{l}\text { exp per } \\
\text { student }\end{array}$ & eff \\
\hline \multirow{3}{*}{ eff } & $\begin{array}{c}\text { Pearson } \\
\text { Correlation } \\
\end{array}$ & $-.259^{* *}$ & $-.196^{*}$ & $-.329^{* *}$ & -.077 & -.031 & -.083 & $-.293^{* *}$ & -.113 & 1 \\
\hline & $\begin{array}{c}\text { Sig. } \\
\text { (2-tailed) }\end{array}$ & .004 & .031 & .000 & .403 & .735 & .363 & .001 & .217 & \\
\hline & $\mathbf{N}$ & 121 & 121 & 121 & 121 & 121 & 121 & 121 & 121 & 121 \\
\hline \multicolumn{11}{|c|}{ **. Correlation is significant at the 0.01 level (2-tailed). } \\
\hline
\end{tabular}

(Source: Own computation by author based on secondary data)

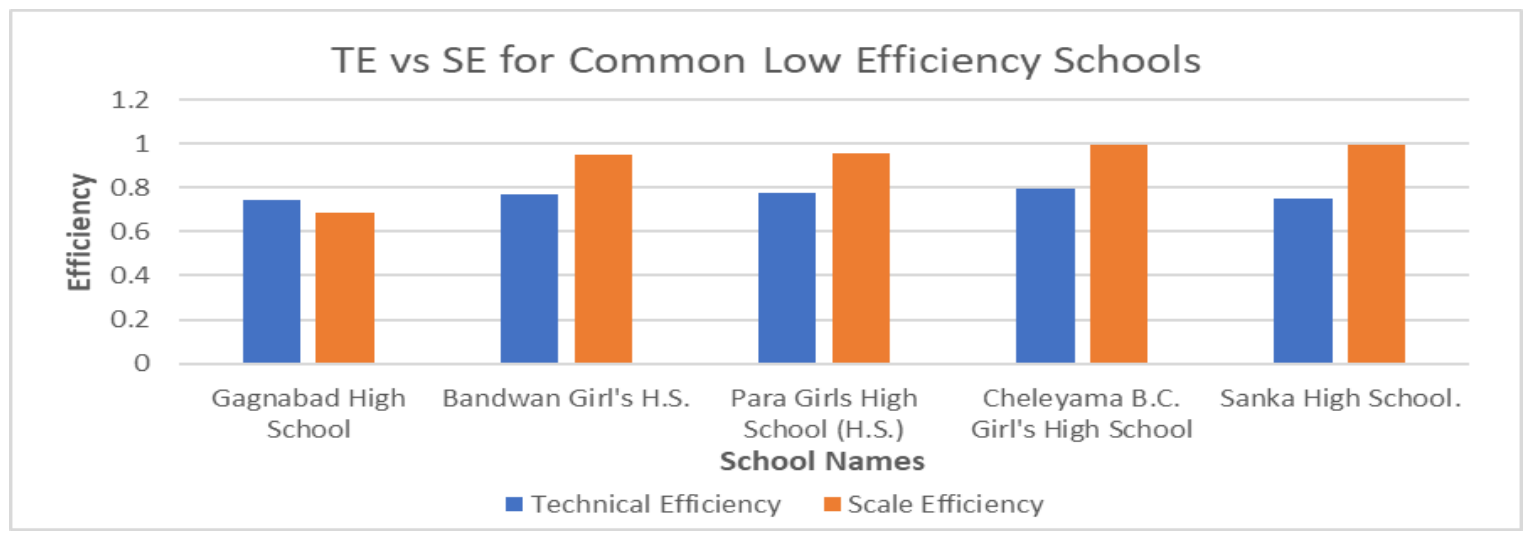

Fig. 4. Technical vs Scale Efficiency for Common Low Efficiency Schools

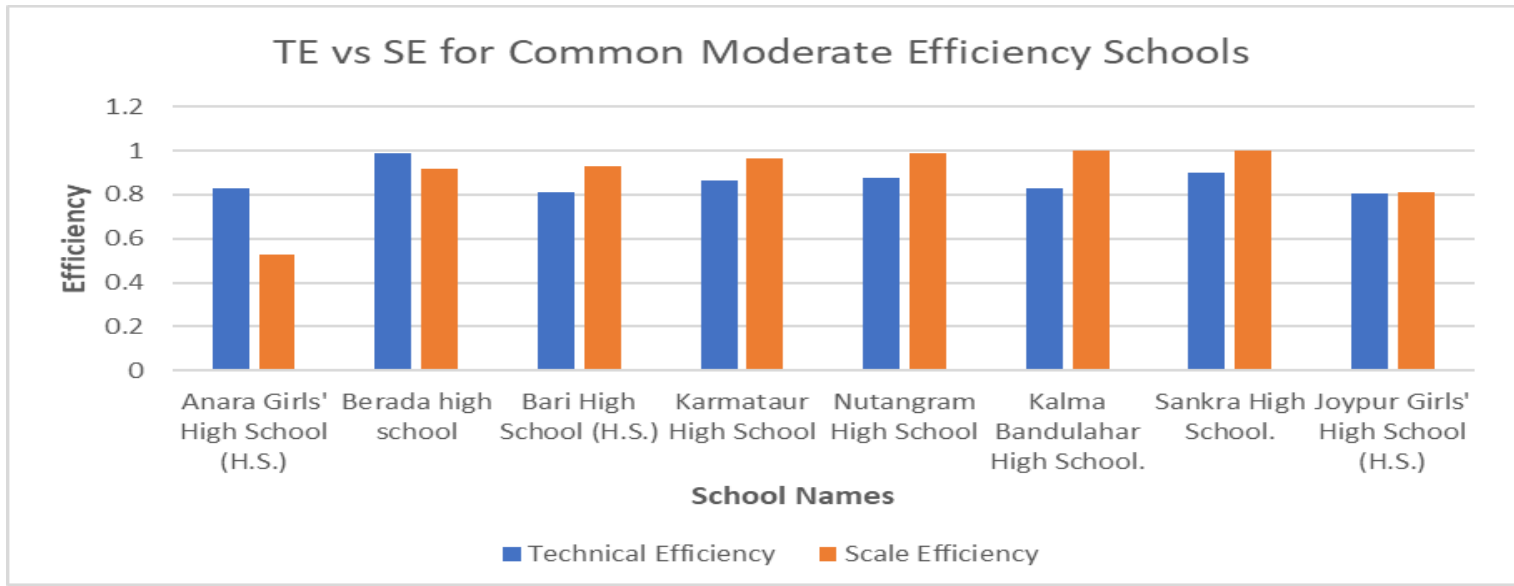

Fig. 5. Technical vs Scale Efficiency for Common Moderate Efficiency Schools

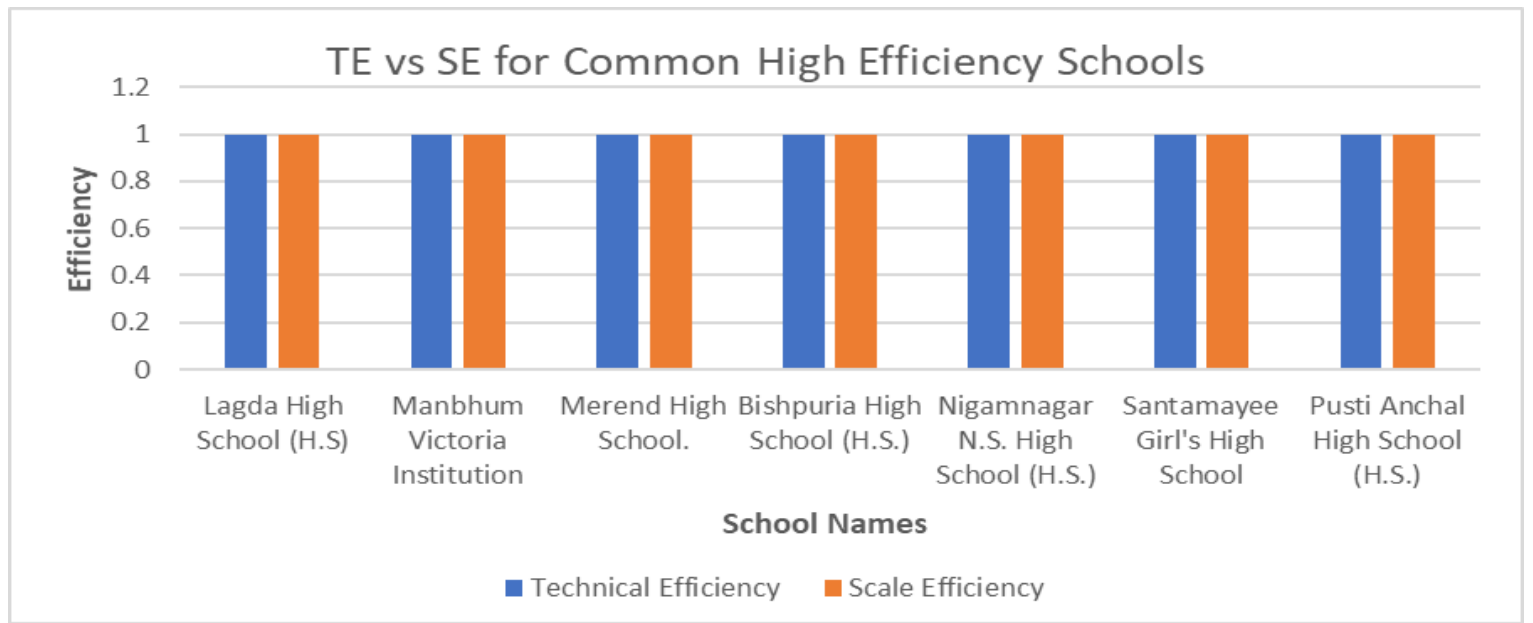

Fig. 6. Technical vs Scale Efficiency for Common High Efficiency Schools

Published By:

Blue Eyes Intelligence Engineering

\& Sciences Publication

(C) Copyright: All rights reserved.

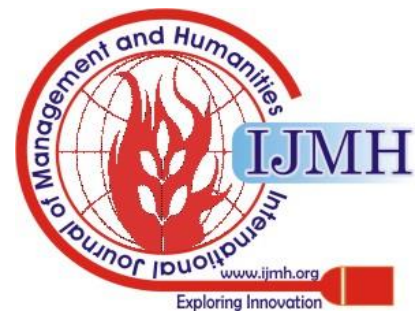


Table III: Statistical description of the socio-economic variables representing the characteristics of 200 sampled students

\begin{tabular}{|c|c|c|c|c|c|c|c|c|c|c|c|c|c|c|c|c|}
\hline & 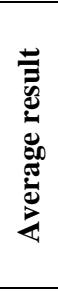 & 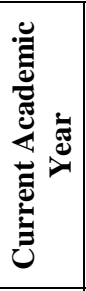 & 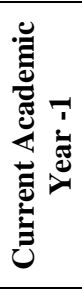 & 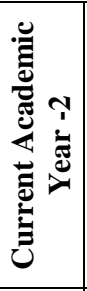 & 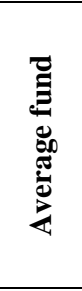 & 苋 & 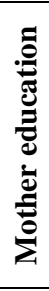 & 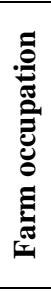 & $\underset{\mathscr{D}}{\stackrel{\mathscr{D}}{ت}}$ & 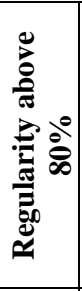 & 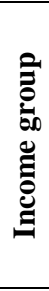 & ڤ્山 & 巻 & 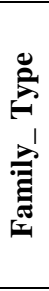 & 离 & 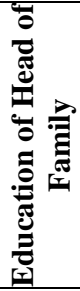 \\
\hline$\sum_{\Sigma}^{\mathbb{J}}$ & 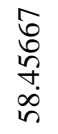 & $\begin{array}{l}\text { 노 } \\
\infty \\
\text { เீं }\end{array}$ & $\begin{array}{l}0 \\
\emptyset \\
\infty \\
ٌ\end{array}$ & $\begin{array}{l}\text { 웅 } \\
\text { லீ }\end{array}$ & $\begin{array}{l}\text { N } \\
\text { } \\
\text { చె }\end{array}$ & $\begin{array}{l}+ \\
\text { ஸे } \\
\text { ஸ் }\end{array}$ & $\stackrel{8}{\varrho}$ & $\hat{0}$ & $\frac{n}{\stackrel{n}{\nu}}$ & $\stackrel{\text { ஜ̊ }}{\circ}$ & 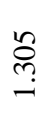 & $\begin{array}{l}\stackrel{1}{O} \\
\stackrel{P}{\circ}\end{array}$ & $\begin{array}{l}\text { న } \\
\text { 'ర } \\
\infty \\
\infty \\
0\end{array}$ & $\vec{\nabla}$ & $\begin{array}{l}\text { J } \\
\stackrel{\Xi}{ت} \\
\dot{0}\end{array}$ & $\begin{array}{l}\text { صै } \\
\text { ขִ } \\
\sigma\end{array}$ \\
\hline 茎 & $\begin{array}{l}m \\
m \\
m \\
m \\
\infty \\
\infty\end{array}$ & กิ & คి & ఠ & 용 & 윰 & $\infty$ & $\neg$ & 0 & 0 & $\neg$ & 0 & 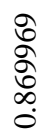 & $\neg$ & 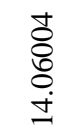 & $\stackrel{ }{ }$ \\
\hline 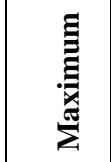 & $\begin{array}{l}\widehat{\vartheta} \\
\emptyset \\
\emptyset \\
\emptyset \\
\infty\end{array}$ & க̊ & $\infty$ & 느 & $\begin{array}{l}\stackrel{8}{8} \\
\stackrel{+}{+}\end{array}$ & $\begin{array}{l}8 \\
8 \\
\varnothing\end{array}$ & $\widehat{ન}$ & $\neg$ & $\neg$ & $\neg$ & م & $\neg$ & $\neg$ & $\neg$ & 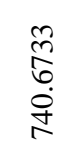 & 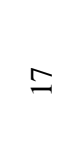 \\
\hline$\underset{\Xi}{\Xi}$ & $\begin{array}{l}\hat{b} \\
b \\
\emptyset \\
\stackrel{\nu}{N}\end{array}$ & $\stackrel{\infty}{\sim}$ & $\stackrel{\curvearrowright}{ }$ & ฟิ & $\underset{8}{8}$ & 0 & 0 & 0 & 0 & 0 & $\neg$ & 0 & \begin{tabular}{l}
$\hat{\theta}$ \\
\multirow{J}{*}{} \\
$\dot{J}$ \\
$\dot{0}$
\end{tabular} & 0 & $\begin{array}{l}m \\
\mathscr{D} \\
\emptyset \\
\mathscr{0} \\
\mathscr{0} \\
0\end{array}$ & 0 \\
\hline 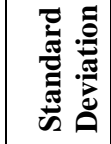 & 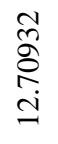 & 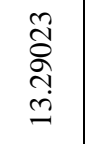 & 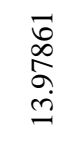 & 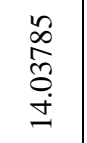 & $\begin{array}{l}\hat{N} \\
\hat{N} \\
\stackrel{N}{N}\end{array}$ & 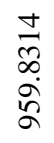 & $\begin{array}{l}\text { స̃ } \\
\text { న్ } \\
\text { જ़ } \\
\dot{\forall}\end{array}$ & 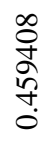 & 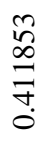 & 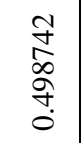 & $\begin{array}{l}\tilde{N} \\
\tilde{N} \\
\tilde{0}\end{array}$ & 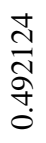 & 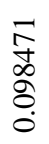 & 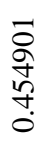 & 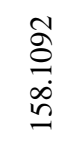 & 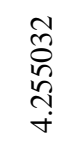 \\
\hline 总 & 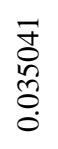 & $\begin{array}{l}0 \\
\infty \\
0 \\
0 \\
0 \\
0 \\
0\end{array}$ & 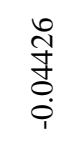 & 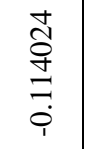 & 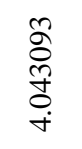 & 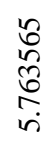 & 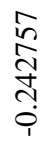 & $\begin{array}{l}\mathcal{N} \\
\infty \\
\stackrel{N}{N} \\
\infty \\
0 \\
1\end{array}$ & 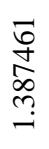 & 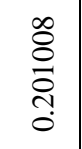 & 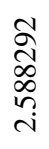 & $\begin{array}{l}\stackrel{0}{0} \\
\infty \\
\infty \\
0 \\
0\end{array}$ & $\begin{array}{l}\text { Nิ } \\
\text { Nิ } \\
\stackrel{0}{0} \\
\dot{0}\end{array}$ & 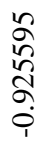 & $\begin{array}{l}m \\
\text { ñ } \\
\text { ஸे }\end{array}$ & 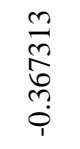 \\
\hline 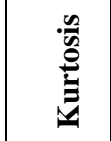 & 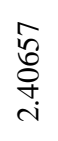 & 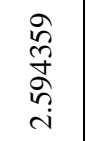 & 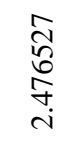 & 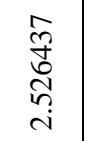 & 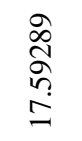 & $\begin{array}{l}0 \\
\text { பे } \\
\text { है } \\
\text { ம் }\end{array}$ & 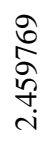 & $\begin{array}{l}\text { 영 } \\
\text { ब } \\
\frac{6}{1}\end{array}$ & 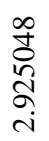 & 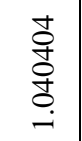 & 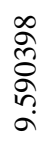 & 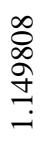 & $\begin{array}{l}0 \\
0 \\
\infty \\
0 \\
\text { ஸึ } \\
\end{array}$ & $\begin{array}{l}\hat{N} \\
\hat{\omega} \\
\infty \\
\infty \\
\end{array}$ & 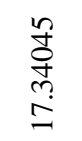 & 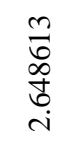 \\
\hline 莺 & $\begin{array}{l}\infty \\
\infty \\
\stackrel{1}{\Lambda} \\
\widehat{N} \\
\text { N่ }\end{array}$ & 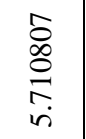 & 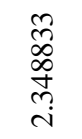 & 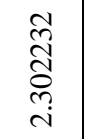 & $\begin{array}{l}\text { Pे } \\
\text { के } \\
\stackrel{\text { ஸे }}{ }\end{array}$ & 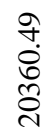 & 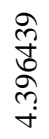 & 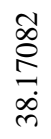 & 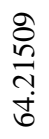 & $\begin{array}{l}\text { J } \\
\text { ஸे } \\
\text { mं } \\
\text { mं }\end{array}$ & $\begin{array}{l}m \\
\text { ஸ̂ } \\
\text { ஸ் } \\
\infty \\
\text { ம் }\end{array}$ & 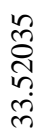 & 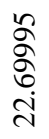 & $\begin{array}{l}\text { す } \\
\text { Oे } \\
\text { 寸े. } \\
\text { வ் }\end{array}$ & 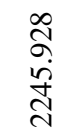 & 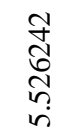 \\
\hline 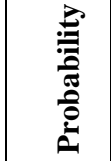 & 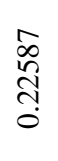 & $\begin{array}{l}m \\
m \\
\stackrel{n}{0} \\
\stackrel{0}{0} \\
\dot{0}\end{array}$ & 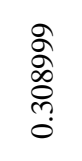 & 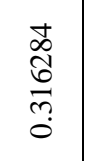 & 0 & 0 & $\begin{array}{l}\text { 옹 } \\
\text { 검 } \\
\text { ㄱ. }\end{array}$ & 0 & 0 & 0 & 0 & 0 & $\begin{array}{l}\mathcal{1} \\
8 \\
8 \\
8 \\
8\end{array}$ & 0 & 0 & $\begin{array}{l}\text { ㅇ } \\
\text { ᄋे } \\
\text { ֶి } \\
\stackrel{0}{0}\end{array}$ \\
\hline$\Xi$ & 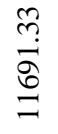 & 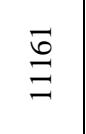 & $\begin{array}{l}\text { ָิ } \\
\underset{-}{ન}\end{array}$ & $\begin{array}{l}\underset{\infty}{-1} \\
\stackrel{-}{\sim}\end{array}$ & 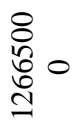 & 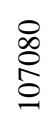 & $\underset{ت}{\stackrel{\Xi}{\Xi}}$ & 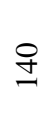 & $\stackrel{m}{\forall}$ & คి & שै & $\grave{\infty}$ & $\begin{array}{l}\infty \\
\text { ஸू } \\
\text { ñ } \\
\text { Ñ }\end{array}$ & $\stackrel{\underset{Ð}{ \pm}}{\sim}$ & 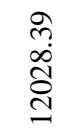 & $\begin{array}{l}0 \\
\stackrel{\infty}{\infty} \\
\end{array}$ \\
\hline 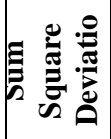 & 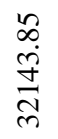 & $\begin{array}{l}\text { ले } \\
\text { 守 } \\
\text { ம் }\end{array}$ & $\begin{array}{l}\infty \\
\infty \\
+ \\
\infty \\
\infty \\
\infty \\
\infty\end{array}$ & 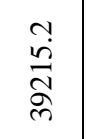 & 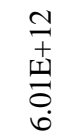 & 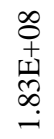 & $\begin{array}{l}\stackrel{\infty}{N} \\
\stackrel{m}{m} \\
m\end{array}$ & $\stackrel{\sim}{\sim}$ & $\begin{array}{l}\text { ஸि } \\
\text { ले }\end{array}$ & ஸุ & 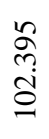 & 祭 & $\begin{array}{l}\text { ஜ } \\
\text { ஜू } \\
\text { హิ }\end{array}$ & $\underset{\sim}{\stackrel{\infty}{\sim}}$ & 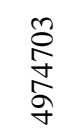 & 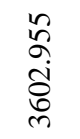 \\
\hline
\end{tabular}

\footnotetext{
(Source: Own computation by author based on secondary data)
}

Published By:

Blue Eyes Intelligence Engineering

\& Sciences Publication

(C) Copyright: All rights reserved.

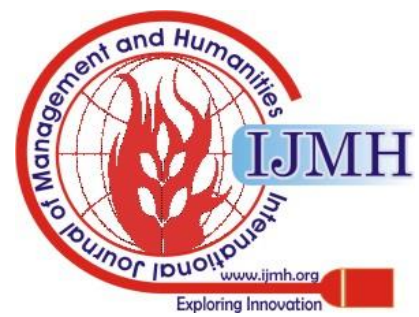


A Non-parametric Estimation for Efficacy of Government Expenditure on Secondary Education

Table IV: Result of the analysis of the impact of Technical Efficiency and socio-economic variables on students' personal achievement

\begin{tabular}{|c|c|c|c|c|}
\hline \multicolumn{5}{|c|}{$\begin{array}{l}\text { Dependent Variable: AVERAGE } \\
\text { RESULT }\end{array}$} \\
\hline \multicolumn{5}{|l|}{ Method: Least Squares } \\
\hline \multicolumn{5}{|l|}{ Sample (adjusted): 1200} \\
\hline \multicolumn{5}{|c|}{ Included observations: 200 after adjustments } \\
\hline Variable & Coefficient & $\begin{array}{l}\text { Standard } \\
\text { Error }\end{array}$ & t-Statistic & Probability \\
\hline Constant & 27.12683 & 7.40323 & 3.664189 & 0.0003 \\
\hline Efficiency under VRS & 26.95162 & 7.622961 & 3.535584 & 0.0005 \\
\hline Sex & 3.574564 & 1.451903 & 2.461986 & 0.0147 \\
\hline Mother Education & 0.125601 & 0.259002 & 0.484942 & 0.6283 \\
\hline $\begin{array}{l}\text { Education of Head of } \\
\text { Family }\end{array}$ & 0.445318 & 0.241773 & 1.841888 & 0.0671 \\
\hline Farm Occupation & -4.107655 & 2.01309 & -2.04047 & 0.0427 \\
\hline Income Group & 1.358174 & 1.175184 & 1.155712 & 0.2493 \\
\hline Tuition Fee & 0.003479 & 0.000794 & 4.379634 & 0 \\
\hline Regularity above $80 \%$ & 7.233434 & 1.391541 & 5.198145 & 0 \\
\hline Caste & -0.927949 & 2.034748 & -0.45605 & 0.6489 \\
\hline Family Type & -1.702637 & 1.546871 & -1.1007 & 0.2724 \\
\hline Worker Population Ratio & -0.072179 & 0.051162 & -1.4108 & 0.16 \\
\hline R-squared & 0.489957 & \multicolumn{2}{|c|}{$\begin{array}{l}\text { Mean dependent } \\
\text { variable }\end{array}$} & 58.45667 \\
\hline Adjusted R-squared & 0.460114 & \multicolumn{2}{|c|}{ S.D. dependent variable } & 12.70932 \\
\hline $\begin{array}{l}\text { Standard Error of } \\
\text { regression }\end{array}$ & 9.338417 & \multicolumn{2}{|c|}{ Akaike info criterion } & 7.364275 \\
\hline Sum Squared Residual & 16394.73 & \multicolumn{2}{|c|}{ Schwarz criterion } & 7.562174 \\
\hline Log likelihood & -724.4275 & \multirow{2}{*}{\multicolumn{2}{|c|}{$\begin{array}{l}\text { Hannan-Quinn criterion } \\
\text { Durbin-Watson statistic }\end{array}$}} & 7.444362 \\
\hline F-statistic & 16.41788 & & & 1.268217 \\
\hline Prob(F-statistic) & 0 & & & \\
\hline
\end{tabular}

(Source: Own computation by author based on secondary data)

We find out that the parameters like efficiency under VRS, sex, farm occupation, tuition fee, regularity above 80 percent are statistically significant in the analysis of the assessment of the impact of the technical efficiency under VRS and the environmental factors on students' personal achievements as shown in Table IV. One-unit increase in T.E. under VRS brings 26.95-unit positive changes in the results of students. Also, one-unit increase in sex parameter increases result by 03.57 unit. One-unit increase in farm occupation decreases the result by 04.11 unit. Though the impact of tuition fee is highly significant, but it affects the result of student positively and in negligible amount of .003. Regularity above 80 percent is highly significant, and one-unit increase in this variable increases the result by 07.23 unit.

\section{CONCLUSION}

The novelty of the work is its contribution at solving the crisis in learning outcomes. The proposed work is expected to provide a clarity in the vision of the policy makers which help them to make a proper policy for qualitative mass education. At the end of the study, we find out that the main determinant of efficiency of secondary education are Student-teacher ratio, percentage of teacher with professional qualification, Percentage of girl's students, student-classroom ratio, not expenditure per student. It is very interesting to note that out of five low efficiency schools, three are girls' schools, out of eight moderate efficiency school, two are girls' school and out of seven high efficiency school one is girls' school. Here we notice a gender biasness. Another noteworthy point we must mention here is that generally schools getting more funds and grants cannot utilize that amount properly. Surprisingly, we observe that there `prevails a strong inverse relationship between $\%$ teacher with professional qualification and efficiency. So, it is evident that in most of the cases, the schools exhibiting high performance are actually dominated by the student's individual performance rather than the school performance.

Therefore, it is high time for the government to address these issues with a new vision. Government should make fund allocation based on performance and should work on the socio-economic aspects of the student to enhance the efficacy on government expenditure of secondary education.

\section{ACKNOWLEDGMENT}

Authors would like to thank Sidho-Kanho-Birsa University, Purulia to carry out the research work and provide all types of the support.

\section{REFERENCES}

1. Max Roser and Esteban Ortiz-Ospina, "Financing Education", 2019 Published online at OurWorldInData.org. Retrieved from: 'https://ourworldindata.org/financing-education' [Online Resource]

Published By:

Blue Eyes Intelligence Engineering DOI:10.35940/ijmh.F0582.024620

Journal Website: www.ijmh.org
\& Sciences Publication

(C) Copyright: All rights reserved.

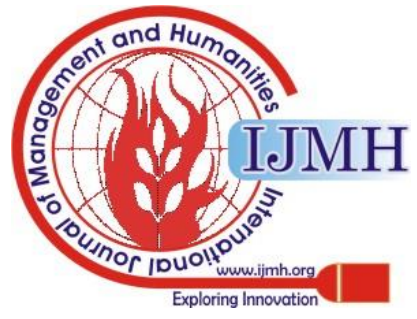


2. Jandhyala B. G. Tilak, "Financing elementary education in India", India Education Report (book), 2001, pp 267-273.

3. Monojit Chatterjee, "Education and economic development in India", SIRE-2008-12, Scottish Institute for Research in Economics, University of Dundee, 2008, pp1-12

4. Khilar, B., "Economics and quality of school education in Sikkim", Ph.D. Dissertation submitted to North Eastern Hill University, 2012.

5. Jana, S.K., and Karmakar, A.K., "Infrastructure, Education and Economic Development in India: A State Level Analysis", in Social, Health, and Environmental Infrastructures for Economic Growth, Edited by R.C Das, IGI Global, 2017.

6. Jana, S.K., Maiti, A. \& Manna, S.S., "An Assessment of Quality of Higher Education Using Six Sigma - A Study in West Bengal, India", Scholars Journal of Arts, Humanities and Social Sciences, Vol. 6 No.1,2018, pp. 259-26.

7. Kirjavainen T., and Loikkanent, H.A., "Efficiency differences of finish senior secondary schools: An application of DEA and Tobit analysis", Economics of Education Review,1998, pp. 377-394.

8. Gupta, Sanjeev \& Verhoeven, Marijn, "The efficiency of government expenditure: experiences from Africa," Journal of Policy Modeling, Elsevier, vol. 23(4), 2001, pp. 433-467.

9. Bradley. S., Johnes.G., Millington. J., "The effect of competition on the efficiency of secondary schools in England", European Journal of Operational Research, Volume 135, Issue 3, 2001, pp. 545-568

10. Baldacci, Emanuele \& Teresa Guin-Siu, Maria \& de Mello, Luiz, "More on the effectiveness of public spending on health care and education: a covariance structure model", Journal of International Development 15(6), 2003, pp. 709-725 ·

11. Baldacci, Emanuele \& Clements, Benedict \& Gupta, Sanjeev \& Cui, Larry., Social Spending, Human Capital, and Growth in Developing Countries. World Development. 36(8), 2008, pp. 1317-1341. 10.1016/j.worlddev.2007.08.003.

12. Jill Johnes, "Data envelopment analysis and its application to the measurement of efficiency in higher education", Economics of Education Review, Volume 25, Issue 3, 2006, pp. 273-288.

13. Davutyan, N, Demir, M. Polat, S., "Assessing the efficiency of Turkish secondary education: Heterogeneity, centralization, and scale diseconomies", Socio-Economic Planning Sciences, Volume 44, Issue 1,2010, pp. 35-44.

14. Ramzi, S., Afonso, A., and Ayadi, M., "Assessment of efficiency in basic and secondary education in Tunisia: A regional analysis", International Journal of Educational Development, Volume 51, 2016, pp 62-76

15. Hužvár, M., \& Rigová, Z.,, "Efficiency of Education Expenditure in OECD Countries. Applications of Mathematics and Statistics in Economics 2016". Conference Proceedings. ISSN 2453-9902, 2016, pp.152-162.

16. Aldamak, A., and Zolfaghari, S., "Review of efficiency ranking methods in data envelopment analysis", Measurement, Volume 106, 2017, pp. 161-172.

17. Aparicio, J , Cordero, J. M. ,Gonzalez, M, and Lopez-Espin, J.J., “Using non-radial DEA to assess school efficiency in a cross-country perspective: An empirical analysis of OECD countries", Omega, Volume 79, 2018, pp 9-20.

\section{AUTHORS PROFILE}

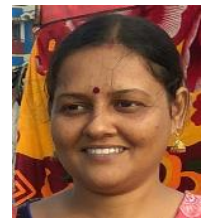

Moumita Khowas, was born in Asansol, West Bengal, India on $10^{\text {th }}$ December, 1979. She received the bachelor's in economics with Honors from Burdwan University, India in 2001, and the master's degree in economics in 2003 from the Jadavpur University, India. She has perusing her Ph.D. (Economics) from SKBU, Purulia, India. Her major field of study is in Economics.

She is currently working as Asst. Teacher in the Gobindapur High School (H.S), Purulia, India. Her research and teaching interests include Microeconomics. She has also authored several research papers and books in the related field.

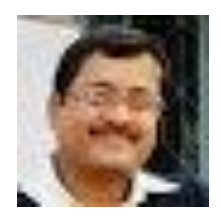

Supravat Bagli, received his BA (Honours), MA Economics, M. Phil Economics and Ph. D. in Economics from The University of Burdwan in 1997, 1999, 2002 and 2011 respectively. In 2012, he joined Sidho-Kanho-Birsha University, Purulia, West Bengal as Assistant Professor in Economics and currently he is engaged as Associate Professor in the Department of Economics, Presidency University, Kolkata. He has authored several reputed journal and conference publications. His area of interest includes Microeconomics, Public Economics, Applied Econometrics, and Time
Series Econometrics. He is also life member of The Indian Econometric Society, and Bengal Economic Association.

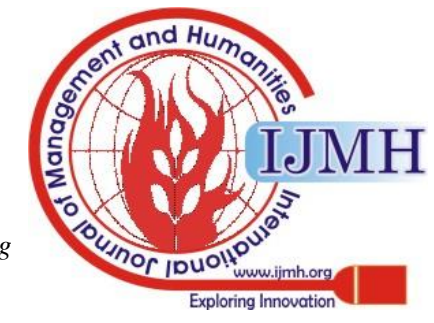

